\title{
Changes in bacterial community structure in seawater mesocosms differing in their nutrient status
}

\author{
Philippe Lebaron ${ }^{1, *}$, Pierre Servais ${ }^{2}$, Marc Troussellier ${ }^{3}$, Claude Courties $^{4}$, \\ Josep Vives-Rego ${ }^{5}$, Gerard Muyzer ${ }^{6, * *}$, Laetitia Bernard ${ }^{1}$, Teresa Guindulain ${ }^{5}$, \\ Hendrik Schäfer ${ }^{6, * *}$, Erko Stackebrandt ${ }^{7}$ \\ ${ }^{1}$ Observatoire Océanologique, Université Pierre et Marie Curie, UMR-7621 CNRS, Institut National des Sciences de \\ I'Univers, BP 44, 66651 Banyuls-sur-Mer Cedex, France \\ ${ }^{2}$ Groupe de Microbiologie des Milieux Aquatiques, Université Libre de Bruxelles, Campus de la Plaine, CP 221, \\ boulevard du Triomphe, 1050 Bruxelles, Belgium \\ ${ }^{3}$ Laboratoire d'Hydrobiologie Marine - UMR CNRS 5556, Université Montpellier II, 34095 Montpellier Cedex 05, France \\ ${ }^{4}$ Observatoire Océanologique, Université Pierre et Marie Curie, UMR-7628 CNRS, BP 44, 66651 Banyuls-sur-Mer Cedex, France \\ ${ }^{5}$ Departament de Microbiologia, Universitat de Barcelona, Av. Diagonal 645, 08028 Barcelona, Spain \\ ${ }^{6}$ Max-Planck-Institut für Marine Mikrobiologie, Fahrenheitstraße 1, 28359 Bremen, Germany \\ ${ }^{7}$ Deutsche Sammlung von Mikroorganismen und Zellkulturen GmbH (DSMZ), Mascheroder Weg 1B, \\ 38124 Braunschweig, Germany
}

\begin{abstract}
Quantitative and qualitative changes in bacterial communities from the Mediterranean Sea were analysed under eutrophication conditions simulated in batch mesocosms (addition of inorganic nutrients or phytoplanktonic lysate). A wide variety of methods including traditional microbial ecology techniques, molecular biology and flow cytometry were combined to determine abundances, production, cell size, activity, culturability, and genetic and taxonomic diversity. In all mesocosms, the increase in biomass was rapidly controlled by protozoan grazing. Morphological and physiological changes were observed during the growth phase of bacteria and under grazing pressure. The proportion of medium-size and culturable cells increased during the growth phase. Grazing eliminates preferentially active and medium-sized cells within communities regulating bacterial productivity. Small and large cells were produced as a consequence of grazing pressure, and the large active cells contributed to the remaining productivity after grazing. Although grazing had an effect on the genetic diversity of bacterial communities by eliminating some populations, other species were preserved. It seems that some species such as Alteromonas macleodii may have developed defence strategies to escape predation. We hypothesize that such species may escape grazing by producing small and/or large cells during their growing phase.
\end{abstract}

KEY WORDS: Mesocosm - Eutrophication - Bacteria - Biomass - Production - Diversity - Cell-specific activity · Grazing

\section{INTRODUCTION}

Heterotrophic bacteria are an abundant and important component of aquatic ecosystems. Their role in the

\footnotetext{
-E-mail: lebaron@arago.obs-banyuls.fr

- Present address: Netherlands Institute for Sea Research, PO Box 59, 1790 AB Den Burg. The Netherlands
}

functioning of biogeochemical cycles, energy flow and secondary production is now well established (Ducklow \& Carlson 1992). Although top-down and bottomup controls are widely known concepts in aquatic microbial ecology (Pace \& Cole 1994), there is still disagreement as to whether the abundance and productivity of pelagic bacteria are determined mainly by predators or nutrients (Pernthaler et al. 1997). Further- 
more, from a structural point of view, both predators and nutrients may be major forces shaping the genotypic and phenotypic composition of bacterial communities (Jürgens \& Güde 1994).

Heterotrophic nanoflagellates and ciliates are usually the major consumers of bacteria in aquatic systems (Jürgens \& Güde 1994). However, information about the strategies involved in the predator-prey interactions is scarce. It has been suggested that very small and large bacteria are partly or totally protected from protozoan grazing (Jürgens \& Güde 1994). If filamentous and very small bacteria exhibit an ecologically significant defense strategy against protozoan grazing, it is not known to what extent their selection under grazing pressure affects the taxonomic structure and activity of natural communities and, thus, the ecological role of these communities. The activity level of filamentous cells remains unclear. On the one hand, Pernthaler et al. (1997) suggested that filamentous cells may be inactive; on the other hand, Gasol et al. (1995) suggested that the probability of a bacterium to be active was a linear function of its size. If we accept that the larger the cells, the higher their activity, the selection of large bacteria may result in the selection of very active and productive cells. Inversely, the selection of small cells may result in the selection of non-active cells.

There is a need to further understand the role of bottom-up and top-down controls on the physiological, taxonomic and functional diversity of natural communities and to understand how this diversity can be affected by changing environmental factors. Bottomup control may play an important role in coastal eutrophized areas, depending on the nature and availability of inorganic and organic nutrients. Although these questions have long been unanswered due to methodological limitations, the recent development of new techniques including flow cytometry and molecular techniques may help to obtain new information.

The introduction of molecular biological techniques in microbial ecology has provided new approaches to the investigation of the structure of microbial communities (Ward et al. 1990, Muyzer et al. 1995). Phylogenetic analyses provide information on bacterioplankton population diversity, as well as nucleic acid probes, which can be used to establish the significance of cultured microorganisms and to study the temporal and spatial distributions of microbial taxa in marine ecosystems (Delong et al. 1993, Mullins et al. 1995).

The aim of this study was to analyse the effect of 2 simulated eutrophication conditions (addition of inorganic and organic nutrients) on changes in morphological, physiological and genetic diversity of bac- terial communities. Thus, this study combines classical microbiological methods and techniques commonly used in microbial ecology with the recent cytometric and molecular biology tools.

\section{MATERIAL AND METHODS}

Experimental set-up. The mesocosms consisted of 3 rectangular tanks of $400 \mathrm{l}$ capacity, $60 \mathrm{~cm}$ height, $60 \mathrm{~cm}$ width and $110 \mathrm{~cm}$ length. Each mesocosm was filled with $300 \mathrm{l}$ of natural seawater collected from $1 \mathrm{~m}$ depth at a station $\left(42^{\circ} 31^{\prime} \mathrm{N}, 03^{\circ} 11^{\prime} \mathrm{E}\right)$ located 2 miles $(-3.2 \mathrm{~km})$ off Banyuls-sur-Mer, France (Mediterranean Sea). Natural seawater was filtered through a $200 \mu \mathrm{m}$ nylon mesh. This filtration removed large metazoans and detritus. Each mesocosm was temperature-controlled to fit the temperature of Mediterranean coastal waters at the time of the experiment by placing the mesocosms into larger tanks $(30 \mathrm{~cm}$ height, $80 \mathrm{~cm}$ width, $140 \mathrm{~cm}$ length) continuously alimented by natural seawater pumped from the shore. The temperature of the water was 17.7 to $19.6^{\circ} \mathrm{C}$ during the experiment. Two mesocosms (Mesocosms A and B) were illuminated by a fluorescent ramp consisting of 5 tubes (36 W, $120 \mathrm{~cm}$ ) providing illumination on a $12: 12 \mathrm{~h}$ light:dark period. Mesocosm $C$ was non-illuminated. Photosynthetically active irradiance (PAR) was measured with a Li-cor quantum sensor. The PAR at the upper part of Mesocosms A and B was $200 \mu \mathrm{E} \mathrm{m} \mathrm{m}^{-2} \mathrm{~s}^{-1}$. The mesocosms were mixed by means of an immersed pump taking water from 2 opposite bottom corners and driving the water back below the surface.

Mesocosm preparation. The chemical compositions of seawater before and after the different treatments are reported in Table 1. Mesocosm A was used as a control to follow changes within the initial community without any nutrient addition. Mesocosm B was supplemented with inorganic nitrogen $\left(\mathrm{NH}_{4}, \mathrm{NO}_{3}\right)$ and phosphorus $\left(\mathrm{PO}_{4}\right)$. Mesocosm $\mathrm{C}$ was supplemented with a mixture of 2 phytoplanktonic species: Chaetoceros sp. and Porphyridium cruentum. Each culture was first frozen and immediately autoclaved to facilitate cell lysis and then

Table 1. Nutrient concentrations $(\mu \mathrm{M})$ of nitrate, ammonium and phosphate, $\mathrm{N}: \mathrm{P}$ ratios and dissolved organic carbon (DOC) concentrations ( $\mu \mathrm{M} C$ ) in the natural seawater used for the experiments and in each mesocosm after the nutrient enrichments were performed ( $\mathrm{SD}, \mathrm{n}=3$ )

\begin{tabular}{|lrccrrr|}
\hline & Nitrate & Ammonium & Phosphate & N:P & \multicolumn{1}{c|}{ DOC } \\
\hline Natural seawater & $0.28(0.15)$ & $0.13(0.03)$ & $0.03(0.02)$ & 13.6 & $146.8(11.2)$ \\
Mesocosm A & $0.32(0.12)$ & $0.17(0.05)$ & $0.05(0.03)$ & 9.9 & $175.5(15.5)$ \\
Mesocosm B & $2.45(0.25)$ & $1.98(0.09)$ & $0.66(0.03)$ & 6.7 & $146.8(25.8)$ \\
Mesocosm C & $38.8(0.19)$ & $1.51(0.05)$ & $0.76(0.05)$ & 53.1 & $343.8(45.8)$ \\
\hline
\end{tabular}


filtered onto $0.2 \mu \mathrm{M}$ membrane filters (Millipore). Four liters of each culture were mixed and added to the mesocosm. Mesocosm C was supplemented after $113 \mathrm{~h}$ since it was not possible to process all mesocosms at the same time.

Sampling strategy. Five liters from each mesocosm were taken daily to analyse nutrients, phyto- and bacterioplankton counts, bacterial production and chlorophyll $a$. The temporal evolution of total bacterial counts was used to determine the sampling times at which all other parameters including the bacterial genetic diversity were also analysed. For these points, $10 \mathrm{l}$ were taken and mixed. These sampling times were chosen corresponding to the starting time of each mesocosm, to the first significant increase in bacterial counts, and to the peak, and then after a significant decrease of total counts and at the end of experiments defined by the stabilisation of total counts.

Nitrogen and phosphorus analysis. For nitrate and phosphate determination, subsamples were collected in polyethylene bottles and directly frozen $\left(-18^{\circ} \mathrm{C}\right)$ for later analysis. Nitrate and phosphate concentrations were determined with a Skalar autoanalyser according to Treguer \& Le Corre (1975). For ammonium analysis, subsamples were collected in $100 \mathrm{ml}$ glass bottles and processed according to Koroleff's (1976) manual method. The reagents were added immediately after collection and measurements were performed 24 h later using a spectrophotometer (Spectronic 401). The optical density was also measured on each original sample in order to take into account the turbidity of the sample.

Culturable counts. Culturable bacteria were enumerated by plating $100 \mu \mathrm{l}$ of serial dilutions of each water sample onto marine agar plates (MA Difco, Detroit, MI). In preliminary assays R2A medium with a seawater base was also used; however, marine agar was chosen for the assays since it yielded higher counts. After $7 \mathrm{~d}$ of incubation at room temperature (20 $\pm 3^{\circ} \mathrm{C}$ ) colony forming units (CFU) were enumerated. Counts did not increase after prolonged incubation.

Flow cytometry analysis of bacteria. Total counts of SYTO 13-stained bacteria were performed with a FACSCalibur flow cytometer (Becton Dickinson, San Jose, CA) equipped with an air-cooled argon laser (488 nm, $15 \mathrm{~mW}$ ). Living samples were stained with SYTO 13 (Molecular probes, Eugene, OR) at $5 \mu \mathrm{M}$ for $30 \mathrm{~min}$. One $\mu \mathrm{m}$ of fluorescent beads (Polysciences, Warrington, PA) was systematically added to samples in order to normalise cell fluorescence emissions and scatters. According to their fluorescence (FL1) and right angle light scatter (RALS, related to cell size) signatures, different bacterial populations could be discriminated and enumerated. Bacterial enumerations by flow cytometry performed as described above were found to be in close concordance with bacterial enumerations by epifluorescence microscopy after 4,6-diamidino-2-phenylindol (DAPI) staining (del Giorgio et al. 1996a).

In order to calibrate the flow cytometric scatter measurements, bacterial cell lengths and biovolumes were estimated from epifluorescence examination of DAPI stained cells of fixed samples ( $n=17$ ) (Troussellier et al. 1995). The relationship between RALS and cell volumes showed high and significant correlation ( $\mathrm{r}=0.869, \mathrm{p} \leq 0.0001)$. The same correlation was obtained when using cell lengths rather than biovolumes (Troussellier et al. 1999). RALS values were not transformed as equivalent spherical diameters. Several bacterial cell populations were discriminated from RALS, and a green fluorescence (FL1) cytogram was obtained for each sample. Cells with high RALS values were related to long rods observed by epifluorescence micorscopy. From one sample to another, these populations were not exactly located at the same place on cytograms. Thus, in order to objectively group the different populations observed in all analysed samples a clustering method (Ward's algorithm; Ward 1963) was applied to all the identified populations. Each population was characterised by its RALS and FL1 mean values. Clustering was carried out with the 'R package' (Legendre \& Vaudor 1991). Three main clusters with an increasing estimated mean size (cell length) ( $\mathrm{C} 1 \leq 1.0 \mu \mathrm{m}, 1.0 \mu \mathrm{m}<\mathrm{C} 2 \leq 2.5 \mu \mathrm{m}$, and $\mathrm{C} 3>2.5 \mu \mathrm{m})$ were discriminated in each sample.

Microscopic counts of protozoa. The abundance of protozoa was determined by epifluorescence microscopy (Leitz, Laborlux D) after DAPI staining. Twenty $\mathrm{ml}$ of glutaraldehyde-preserved $(0.5 \%$ final concentration) water samples were stained with DAPI $\left(0.1 \mu \mathrm{gl}^{-1}\right.$, final concentration) for $15 \mathrm{~min}$. Filters were mounted on microscopic slides and stored at $+4^{\circ} \mathrm{C}$ until examination. Stained protists were collected by filtration on a $0.8 \mu \mathrm{m}$ pore size black filter (Nuclepore). Pico-sized (0.2 to $2 \mu \mathrm{m}$ in diameter) and nano-sized (2 to $20 \mu \mathrm{m}$ in diameter) micro-organisms were identified, counted and measured at a magnification of $1250 \times$ and $625 \times$ while micro-sized (20 to $200 \mu \mathrm{m}$ in diameter) microorganisms were analysed at a magnification of $125 \times$. A minimum of 100 organisms per filter was counted. Autotrophic species were distinguished from heterotrophs by the red autofluorescence of chlorophyll a observed under blue light excitation. Dinoflagellates, flagellates and ciliates were enumerated distinctly. Data presented in this paper concern only the heterotrophic protozoa.

Respiring cell counts. 5-cyano-2,3-ditolyl tetrazolium chloride reduction (CTC; Polyscience Europe) was used to identify active respiring cells by the method of Rodriguez et al. (1992). CTC was added $(5 \mathrm{mM}$ final concentration) to $2 \mathrm{ml}$ samples. CTC incubations were 
performed in the dark at room temperature during $8 \mathrm{~h}$. The fraction of respiring cells was determined as previously described (Joux et al. 1997).

Bacterial activity and production. Four $10 \mathrm{ml}$ subsamples were incubated in the presence of 4 different concentrations $(6.5,13,26$ and $39 \mathrm{nM})$ of tritiated thymidine (Amersham $84 \mathrm{Ci} \mathrm{mmol}^{-1}$ ) for 1 to $2 \mathrm{~h}$ in the dark at the temperature of the mesocosms. After incubation, cold trichloroacetic acid (TCA) was added ( $5 \%$ final concentration) and the samples were filtered through $0.2 \mu \mathrm{m}$ pore size cellulose acetate membrane. Radioactivity associated with the filters was estimated by liquid scintillation. Incorporation rates expressed in pmol $\mathrm{l}^{-1} \mathrm{~h}^{-1}$ at the different thymidine concentrations were calculated and plotted against the added thymidine concentrations. The maximum incorporation rates were estimated by best fitting a hyperbolic function to the experimental data using a software based on the least squares criterion (Servais 1995). Data presented in the paper are maximum incorporation rates.

Bacterial production (P) expressed in cells produced per unit of volume and time was calculated by multiplying the maximum incorporation rate by a conversion factor equal to $0.5 \times 10^{18}$ cells produced per mole of thymidine incorporated into cold TCA insoluble material (Servais 1992).

Incorporation of ${ }^{3} \mathbf{H}$-leucine. Four $10 \mathrm{ml}$ subsamples were incubated in the presence of 4 different concentrations of leucine ( $2 \mathrm{nM}$ of tritiated leucine, Amersham $151 \mathrm{Ci} \mathrm{mmol}{ }^{-1}$, with $0,25,50,75 \mathrm{nM}$ nonradioactive leucine) for 1 to $2 \mathrm{~h}$ in the dark at the temperature of the mesocosms (Servais 1995). After incubation, cold TCA was added ( $5 \%$ final concentration) and subsamples were heated at $85^{\circ} \mathrm{C}$ for $30 \mathrm{~min}$ after acidification following the procedure proposed by Kirchman et al. (1985) to specifically measure the incorporation into proteins. After cooling, the samples were filtered through $0.2 \mu \mathrm{m}$ pore size cellulose acetate membrane. Maximum incorporation rates into proteins were calculated as for thymidine incorporation. Data presented in the paper are maximum incorporation rates into proteins.

Growth rate. Growth rates $\left(\mu, \mathrm{h}^{-1}\right)$ were calculated using the following model: specific growth rate $\mu=\ln (1+\mathrm{P} / \mathrm{N})$, where $\mathrm{P}$ is cellular production (cells $\mathrm{I}^{-1}$ $\mathrm{h}^{-1}$ ) and $\mathrm{N}$ is bacterial abundance (cells $\mathrm{l}^{-1}$ ) (Lovejoy et al. 1996). Doubling time (h) was calculated as $(\ln 2) / \mu$.

Denaturing gradient gel electrophoresis (DGGE) analysis. Water samples were taken from the mesocosm and approximately $2.5 \times 10^{8}$ bacterial cells were collected by filtration (Millipore GVWP 02500, $0.22 \mu \mathrm{m}$, $25 \mathrm{~mm} \varnothing$ ). Filters were frozen in liquid nitrogen immediately. DNA and IRNA were extracted and purified from filters as described by Teske et al. (1996). The extracted genomic DNA was used as target DNA in the polymerase chain reaction (PCR; Saiki et al. 1988) to amplify fragments of bacterial 16S rRNA genes suitable for subsequent DGGE analysis using primer combinations 341F-GC/907RC and 341F-GC/907RM (Muyzer et al. 1995). At the $5^{\prime}$ end of the forward primer 341F-GC (sequence 5'-CCT ACG GGA GGC AGC AG-3') a 40 bp $G C$-rich sequence (GC-clamp) was attached (sequence: 5'-CGC CCG CCG CGC $\mathrm{CCC}$ GCG CCC GTC CCG CCG CCC CCG CCC G-3'). The 2 reverse primers used differed in 1 nucleotide position, at which 907RM has a degeneracy at a position with some variation in the bacterial target site (primer 907RC: 5'-CCG TCA ATT CCT TTG AGT TT-3' and primer 907RM sequence: 5'-CCG TCA ATT CMT TTG AGT TT-3'). PCR products obtained with the 2 primer sets were used for independent DGGE analyses. DGGE was performed essentially as described by Muyzer et al. (1998) using linear denaturing gradients of 10 to $70 \%$ or 20 to $80 \%$ urea and formamide. After DGGE, electrophoresis gels were stained in an ethidium-bromide solution $\left(0.5 \mathrm{mg} \mathrm{I}^{-1}\right)$ and photographed with a Polaroid system.

For cluster analysis of banding patterns the gel images were analysed for similarities of banding patterns by scoring absence or presence of apparent bands with 0 and 1 , respectively. In this way a binary matrix was created which was subsequently analysed with the UPGMA option in PAUP4 * using the correction of Nei \& Li (1979).

Molecular identification. Preparation of genomic DNA from pure cultures isolated from mesocosms and amplification of $16 \mathrm{~S}$ rDNA by PCR was done as described by Rainey et al. (1996).

Phylogenetic analyses. Sequences were manually aligned with sequences published previously. These were stored in the DSMZ internal database consisting of more than 5000 16S rDNA sequence entries, including those from the Ribosomal Database Project (Maidak et al. 1997) and EMBL. Similarity values were transformed into phylogenetic distance values that compensate for multiple substitutions at any given site in the sequence (Jukes \& Cantor 1969). The neighbor joining method contained in the PHYLIP package (Felsenstein 1993) was used in the construction of phylogenetic dendrograms. All analyses were done on a SUN Sparcll workstation

\section{RESULTS}

\section{Nutrients}

The initial seawater was characterised by low concentrations in phosphate, but the N:P ratio was close to the Redfield ratio (Table 1). The phosphate concentra- 
tions fell close to the detection limit after $144 \mathrm{~h}$ in Mesocosm A (Fig. 1A). Ammonium concentrations were maintained constant at a low concentration. In Meso$\operatorname{cosm} B$, phosphorus was consumed rapidly during the first $5 \mathrm{~d}$ and then stabilised but was never exhausted (Fig. 1B). Inversely, nitrogen fell close to the detection limit after $72 \mathrm{~h}$. Both phosphorous and nitrogen (nitrate and ammonium forms) concentrations were high after addition of the phytoplankton lysate in Mesocosm C and were never exhausted (Fig, 1C).

\section{Bacterial and protistan abundances}

Initial bacterial numbers were about $5 \times 10^{5}$ cells $\mathrm{ml}^{-1}$ in all mesocosms (Fig. 2). Although bacterial abundances increased during the first few days in all mesocosms, this increase was more important in Mesocosm B $\left(5 \times 10^{6}\right.$ cells $\mathrm{ml}^{-1}$ after $\left.120 \mathrm{~h}\right)$. The peaks of abundances were observed after 136,120 and $122 \mathrm{~h}$ in Mesocosms $A, B$ and $C$, respectively. The increase in total bacterial counts was followed by a rapid increase
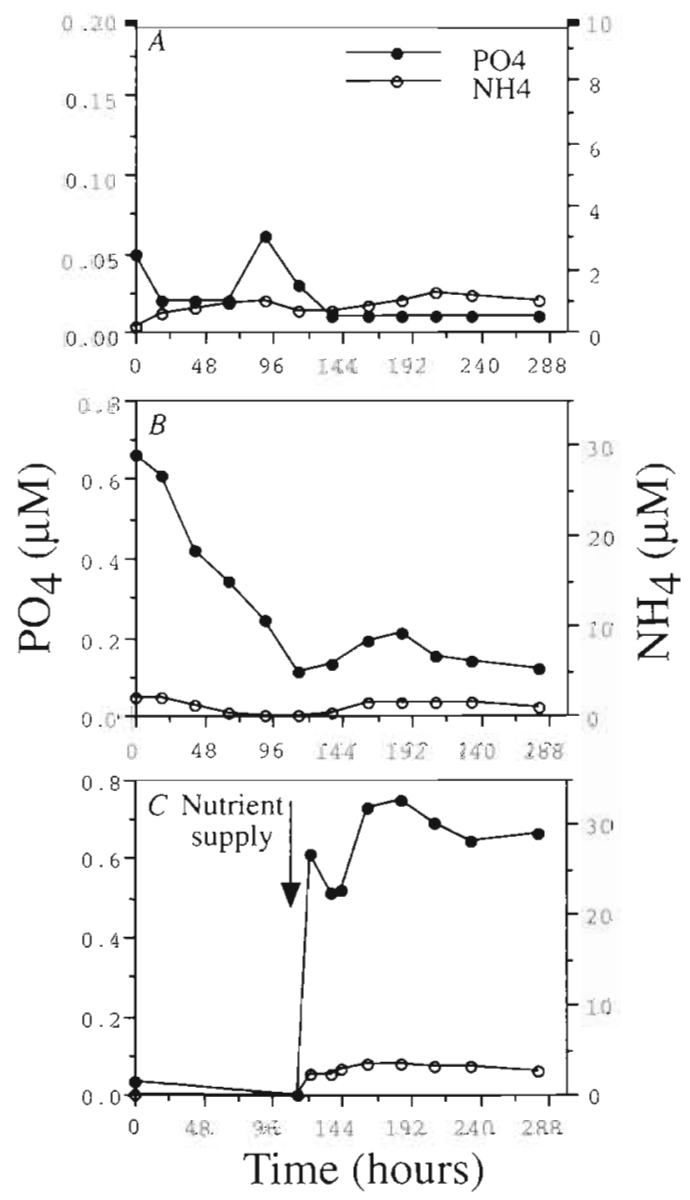

Fig. 1. Temporal changes of phosphorous and ammonium concentrations in Mesocosms A, B and C

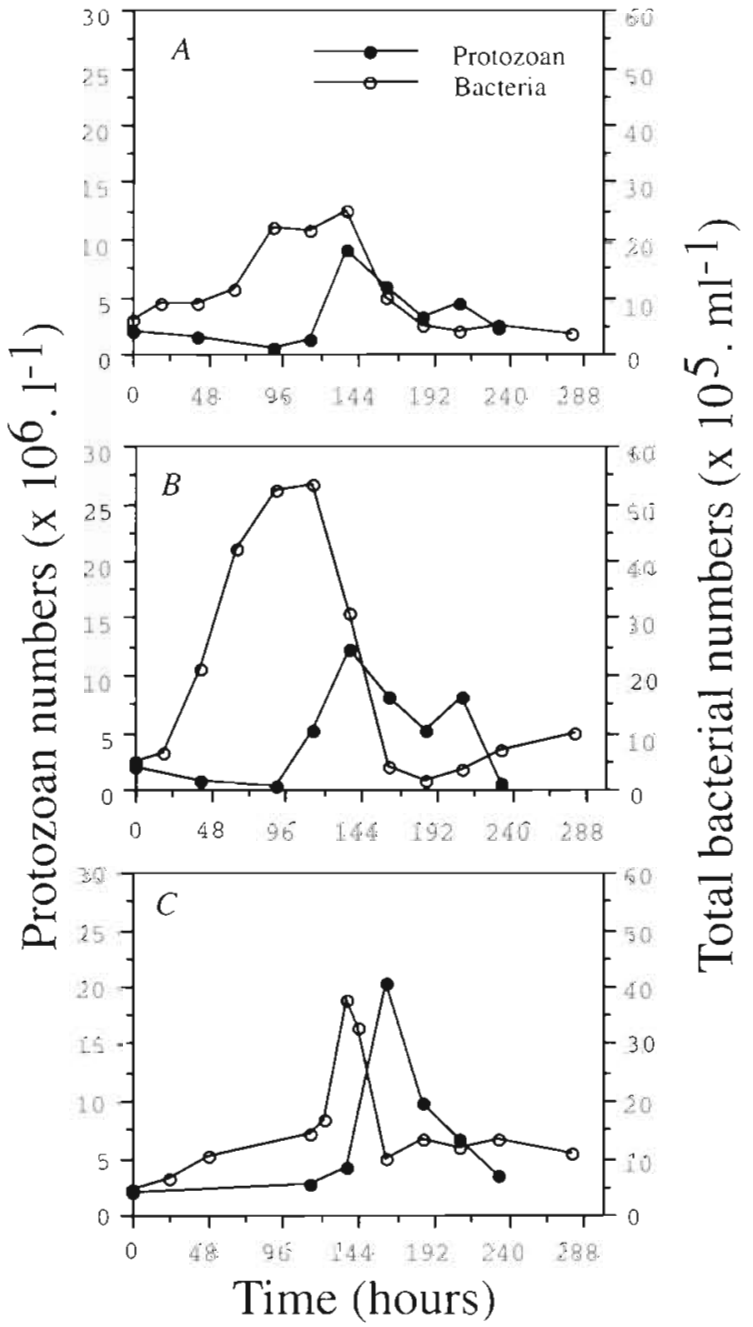

Fig. 2. Temporal changes in total bacterial and protozoan counts in Mesocosms A, B and C

in protozoa counts with a delay of approximately $24 \mathrm{~h}$. The increase in the number of protozoa resulted in a rapid and important decrease of bacterial counts. Then, the grazing pressure was reduced with decreasing bacterial counts. After grazing, the total numbers of bacteria were close to the initial counts.

\section{Bacterial activity}

The rate of ${ }^{3} \mathrm{H}$-thymidine incorporation into DNA was used to estimate bacterial cell replication (Fuhrman \& Azam 1982) and that of ${ }^{3} \mathrm{H}$-leucine into bacterial proteins in order to estimate the protein synthesis rate (Kirchman et al. 1985). Although both methods are usually well correlated (Servais 1992), they give complementary information on the bacterial metabolism as one measures cell multiplication and the other one biomass synthesis (Shiah \& Ducklow 1997). 


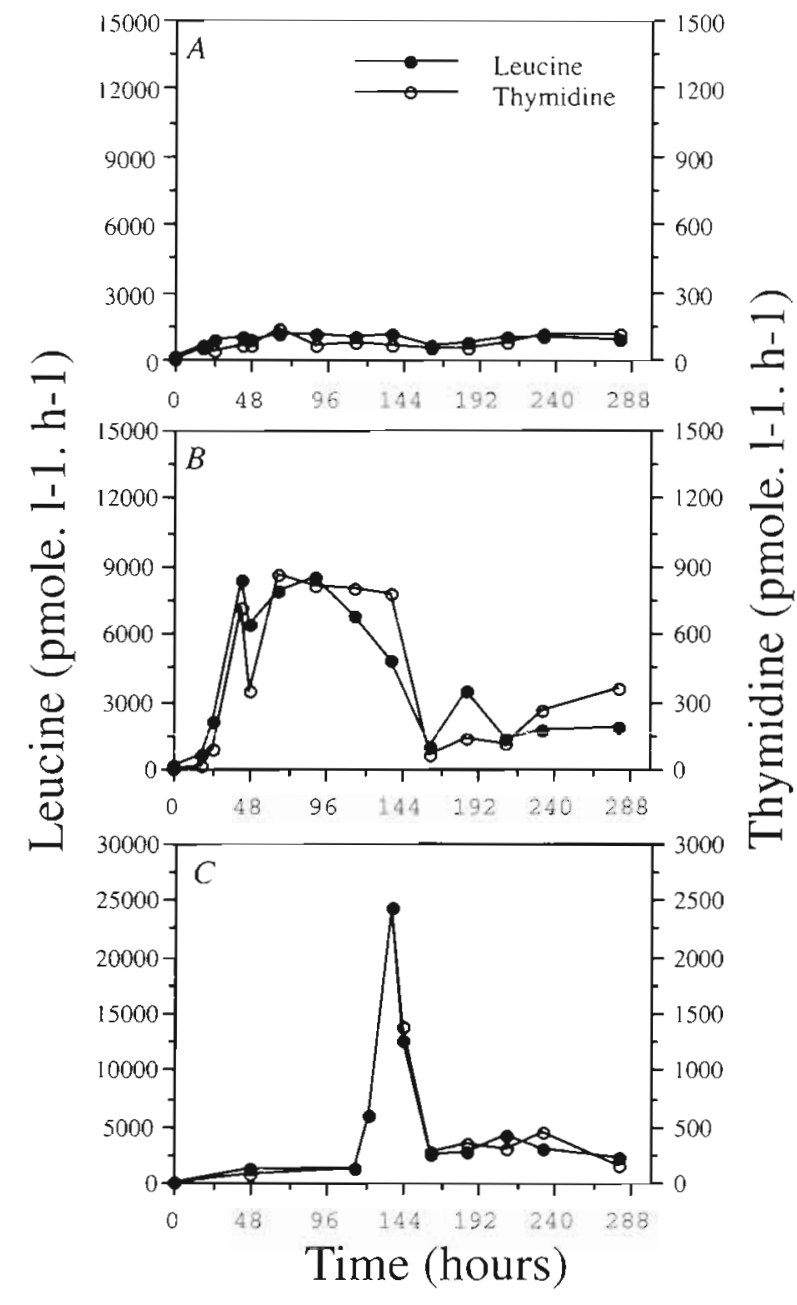

Fig. 3. Changes in leucine and thymidine incorporation rates in Mesocosms A, B and C

Maximum incorporation rates of thymidine and leucine presented the same trends, although slight differences were observed in some situations (Fig. 3). Bacterial production as determined by the rates of leucine incorporation into protein and thymidine incorporation into DNA were low in the initial seawater (respectively 100 pmol leucine $\mathrm{l}^{-1} \mathrm{~h}^{-1}$ of and $2 \mathrm{pmol}$ thymidine $\mathrm{l}^{-1} \mathrm{~h}^{-1}$ ). The incorporation rates increased slightly during the first $3 \mathrm{~d}$ in the control (Mesocosm A) and then stabilised. In Mesocosm B, both incorporation rates increased exponentially until Day 2 and then high activity values were maintained until Day 6 when they fell rapidly within $24 \mathrm{~h}$ to values which remained higher than those measured at the beginning of the experiment. Thereafter, leucine and thymidine incorporation rates remained low. In Mesocosm C, leucine and thymidine incorporation rates increased strongly within $48 \mathrm{~h}$ after nutrient addition (at $113 \mathrm{~h}$ ) and then decreased very rapidly. Maximum values reached on
Day 6 were higher than those obtained in other mesocosms. However, these high values decreased rapidly compared to those reported in Mesocosm B, which were lower but remained high and almost constant during the last 4 to $5 \mathrm{~d}$.

\section{Culturability and activity of bacterial cells}

The fraction of culturable cells was low in the initial seawater (less than $0.1 \%$ ) and increased during the growing phase in all mesocosms (Fig. 4). In the control, the culturability remained low up to $144 \mathrm{~h}$, was maximum $(30 \%)$ at $185 \mathrm{~h}$, and then stabilized between 20 and $30 \%$. The number of actively respiring bacteria increased more rapidly and was higher than culturable counts during the growing phase of bacteria (from 0 to $144 \mathrm{~h}$ ). Active cell counts decreased sharply up to $185 \mathrm{~h}$. In Mesocosm B, both active and culturable cells

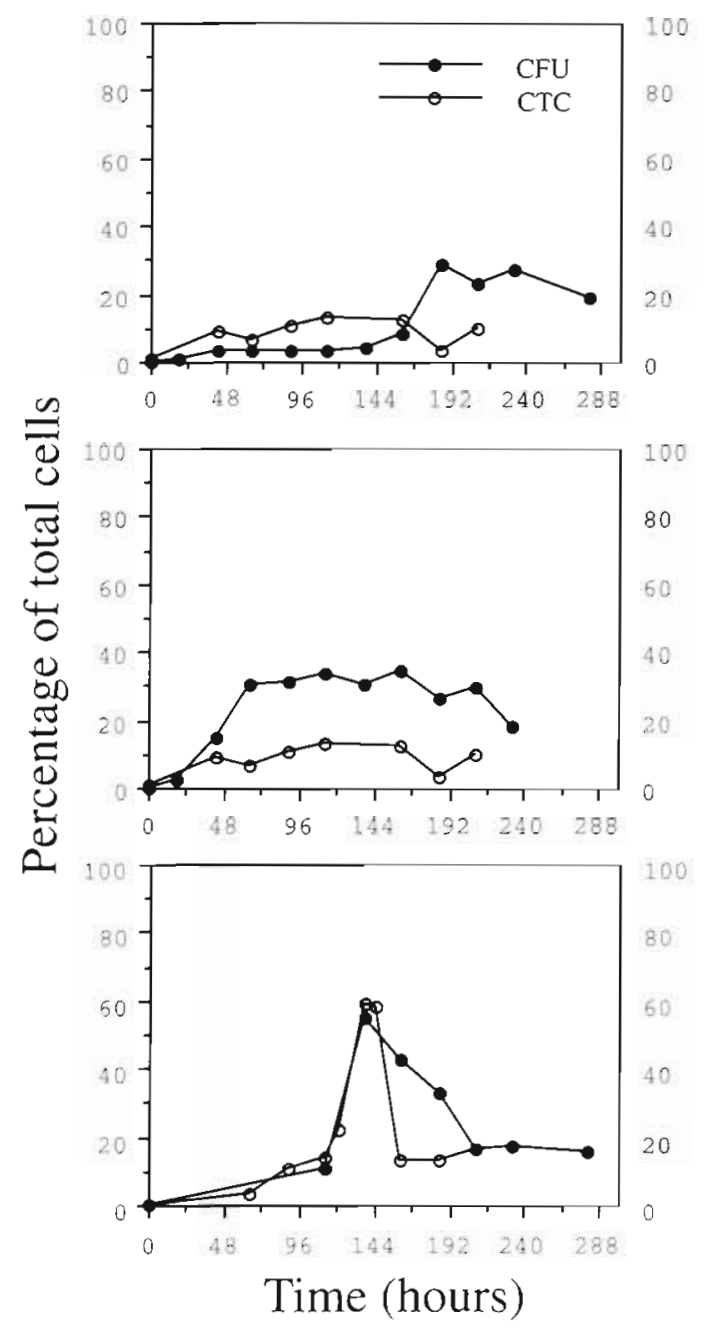

Fig. 4. Percentages of culturable and respiring cells in Mesocosms $\mathrm{A}, \mathrm{B}$ and $\mathrm{C}$ at different sampling times 
increased up to $113 \mathrm{~h}$. The fraction of respiring cells decreased rapidly and remained low after $185 \mathrm{~h}$. Inversely, an important fraction of cells (18 to $35 \%$ ) retained culturability during the grazing phase. In Mesocosm C, there was a concomitant increase in both active and culturable cells followed by a rapid decrease within $24 \mathrm{~h}$. Thereafter, both fractions remained constant and equal to approximately $20 \%$. In all mesocosms, although total cell counts were almost similar at time 0 and after grazing, there were important changes in the community structure.

\section{Bacterial cell biovolume}

In the initial seawater, C1 cells contributed about $50-60 \%$ to total bacterial biovolume (Fig. 5). In all mesocosms the contribution of $\mathrm{C} 1$ cells to total biovolume decreased continuously during the growing phase and was inversely related to an increasing contribution

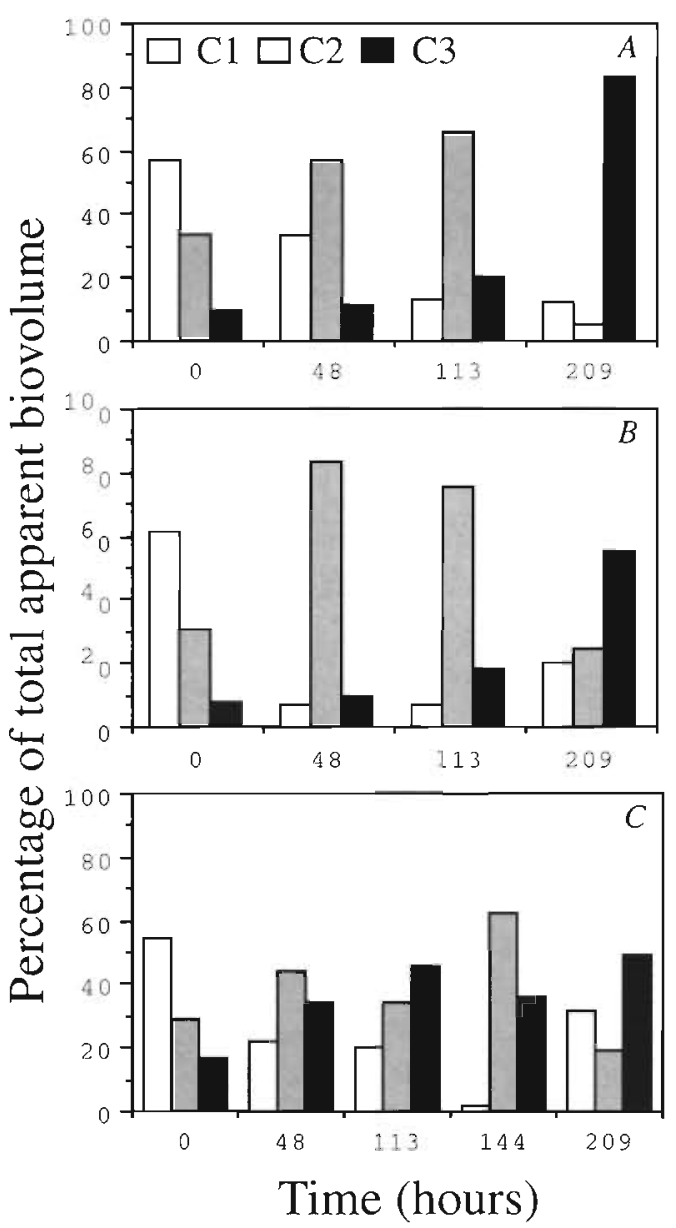

Fig. 5. Contribution of cells within clusters C1, C2 and C3 to the total bacterial biovolume. Clusters were defined from 3 different classes of cell lengths $(\mathrm{C} 1 \leq 1.0 \mu \mathrm{m}, 1.0 \mu \mathrm{m}<\mathrm{C} 2 \leq 2.5 \mu \mathrm{m}$, and $\mathrm{C} 3>2.5 \mu \mathrm{m}$ ) of $C 2$ cells. This inverse trend was more rapid and pronounced in Mesocosm B. In Mesocosm C the trend was similar to that in Mesocosm A during the first slight increase of total bacterial counts and then was amplified within $24 \mathrm{~h}$ after nutrient addition, corresponding to the rapid shift in total counts. Thereafter, there was a rapid decrease in the contribution of $\mathrm{C} 2$ cells which was concomitant with the decrease in total bacterial counts under grazing pressure. There was a pronounced inverse trend of increasing contribution of $\mathrm{C} 1$ and $\mathrm{C} 3$ cells and decreasing contribution of $\mathrm{C} 2$ cells to total biovolume.

\section{Taxon affiliation of selected isolates}

Of the 430 strains isolated from Mesocosms A, B and C, 36 strains were picked to represent the variation of pigments and colony forms. The majority of the analysed organisms belong to the alpha and gamma subclass of Proteobacteria (36 and 44\%, respectively). while the number of Gram-positive bacteria was much smaller $(16 \%)$. The majority of strains clustered close to the described species, e.g. Sulfitobacter pontiacus (99.0 to $99.7 \%$ similarity) and Roseobacter algicola ( 97.0 to $100 \%$ similarity) in the alpha subclass of Proteobacteria, and members of Pseudoalteromonas haloplanktis (99.4 to $100 \%$ similarity), Alteromonas macleodii (95.5\% similarity), Marinobacter hydrocarbonoclasticus (95.6 to $96 \%$ similarity) and Vibrio splendidus ( 95.3 to $97.6 \%$ similarity) in the gamma subclass of Proteobacteria (see Table 2).

\section{Genetic fingerprints from mesocosm water samples and identification of dominant isolates}

The genetic diversity of bacterial communities was also studied at different sampling points of each mesocosm by means of DGGE. According to the DGGE profiles (Fig. 6), there were marked changes in the number and position of bands suggesting temporal modifications of the community structure. The number of apparent bands slightly decreased during the increase of bacterial biomass and then increased again after grazing. Furthermore, important changes in the intensity of the different bands suggested changes in the relative abundance of the different $16 \mathrm{~S}$ rDNA defined populations. Cluster analysis of the banding patterns was performed; the resulting dendrogram is shown in Fig. 7. The samples fell into 2 clusters that represented the status before and after the peak of grazing activity in each mesocosm. Furthermore, consecutive sampling times of mesocosms clustered together (e.g. A065 and A113, B065 and B113, C144 and C185). Also, the patterns of B281 and C281 were similar. 
Table 2. Nearest phylogenetic neighbors of isolates as derived from analyses of the 5'500 nucleotides of the 16S tDNA

\begin{tabular}{|c|c|c|c|}
\hline $\begin{array}{l}\text { Mesocosm } \\
\text { sampling } \\
\text { times (h) }\end{array}$ & Sequence & Nearest phylogenetic neighbor & $\begin{array}{l}\text { 16S rDNA } \\
\text { similarity }\end{array}$ \\
\hline & & Alpha subclass of Proteobacteria & \\
\hline$A, 0$ & $\mathrm{CH}-\mathrm{A} 19$ & Caulobacter strain MCS10 & 98.6 \\
\hline$A, 0$ & $\mathrm{CH}-\mathrm{A} 10$ & Marinosulfonas methylotrophus & 95.5 \\
\hline $\mathrm{A}, 0$ & $\mathrm{CH}-\mathrm{A} 11$ & Roseobacter algicola & 100.0 \\
\hline B, 65 & $\mathrm{CH}-\mathrm{B} 106$ & Roseobacter algicola & 98.3 \\
\hline B, 161 & $\mathrm{CH}-\mathrm{B} 422$ & Roseobacter algicola & 96.7 \\
\hline $\mathrm{B}, 161$ & $\mathrm{CH}-\mathrm{B} 424$ & Roseobacter algicola & 96.3 \\
\hline $\mathrm{B}, 161$ & $\mathrm{CH}-\mathrm{B} 436$ & Roseobacter algicola & 97.0 \\
\hline$A, 0$ & $\mathrm{CH}-\mathrm{A} 24$ & Sulfitobacter pontiacus & 99.7 \\
\hline B, 161 & $\mathrm{CH}-\mathrm{B} 423$ & Sulfitobacter pontiacus & 99.7 \\
\hline B, 161 & $\mathrm{CH}-\mathrm{B} 420$ & Sulfitobacter pontiacus & 99.0 \\
\hline $\mathrm{B}, 161$ & $\mathrm{CH}-\mathrm{B} 425$ & Sulfitobacter pontiacus & 99.0 \\
\hline $\mathrm{B}, 161$ & $\mathrm{CH}-\mathrm{B} 427$ & Sulfitobacter pontiacus & 97.6 \\
\hline \multirow[t]{2}{*}{ B, 161} & $\mathrm{CH}-\mathrm{B} 437$ & Sulfitobacter pontiacus & 99.7 \\
\hline & & Gamma subclass of Proteobacteria & \\
\hline A, 0 & $\mathrm{CH}-\mathrm{A} 21$ & Aeromonas hydrophila & 96.0 \\
\hline C, 185 & $\mathrm{CH}-\mathrm{C} 460$ & Alteromonas macleodii & 95.5 \\
\hline$A, 0$ & $\mathrm{CH}-\mathrm{A} 31$ & Klebsiella pneumoniae & 98.5 \\
\hline A, 0 & $\mathrm{CH}-\mathrm{A} 25$ & Marinobacter hydrocarbonoclasticus & 96.0 \\
\hline $\mathrm{A}, 0$ & $\mathrm{CH}-\mathrm{A} 30$ & Marinobacter hydrocarbonoclasticus & 96.0 \\
\hline B, 161 & $\mathrm{CH}-\mathrm{B} 434$ & Marinobacter hydrocarbonoclasticus & 95.6 \\
\hline A, 0 & $\mathrm{CH}-\mathrm{A} 15$ & Moritella marinus & 91.3 \\
\hline A, 0 & $\mathrm{CH}-\mathrm{A} 32$ & Pseudoalteromonas haloplanktis & 99.4 \\
\hline B, 65 & $\mathrm{CH}-\mathrm{B} 126$ & Pseudoalteromonas haloplanktis & 99.4 \\
\hline C. 137 & $\mathrm{CH}-\mathrm{C} 311$ & Pseudoalteromonas haloplanktis & 100.0 \\
\hline B, 161 & $\mathrm{CH}-\mathrm{B} 426$ & Pseudoalteromonas haloplanktis & 99.7 \\
\hline C, 185 & $\mathrm{CH}-\mathrm{C} 469 \mathrm{~b}$ & Pseudoalteromonas haloplanktis & 100.0 \\
\hline B, 65 & $\mathrm{CH}-\mathrm{B} 107$ & Pseudomonas putida & 97.5 \\
\hline B, 65 & $\mathrm{CH}-\mathrm{B} 105$ & Vibrio splendidus & 95.3 \\
\hline B, 65 & $\mathrm{CH}-\mathrm{B} 108$ & Vibrio splendidus & 97.6 \\
\hline \multirow[t]{2}{*}{ B 65} & $\mathrm{CH}-\mathrm{B} 125$ & Vibrio splendidus & 97.3 \\
\hline & & Clostridium/Bacillus subphylum & \\
\hline A, 0 & $\mathrm{CH}-\mathrm{A} 2$ & Exiguibacterium acetylicum & 96.4 \\
\hline C, 185 & $\mathrm{CH}-\mathrm{C} 469$ & Bacillus pumilus & 99.6 \\
\hline A, 0 & $\mathrm{CH}-\mathrm{A} 22$ & Kocuria rosea & 98.8 \\
\hline \multirow[t]{2}{*}{ A, 0} & $\mathrm{CH}-\mathrm{A} 14$ & Staphylococcus haemolyticus & 100.0 \\
\hline & & Class Actinobacteria & \\
\hline B, 161 & $\mathrm{CH}-\mathrm{B} 429$ & Micrococcus lylae & 100.0 \\
\hline \multirow[t]{2}{*}{$A, 0$} & $\mathrm{CH}-\mathrm{A} 13$ & Rhodococcus fascians & 98.1 \\
\hline & & Cytophaga/Flavobacterium subphylum & \\
\hline $\mathrm{A}, 0$ & $\mathrm{CH}-\mathrm{A} 3$ & Flavobacterium salegens & 95.2 \\
\hline
\end{tabular}

\section{DISCUSSION}

The 3 mesocosm experiments presented herein were done to study the effect of bottom-up and top-down controls on the structure of bacterial communities as affected by 2 laboratory-simulated eutrophication conditions. Although these results did not determine if similar processes occur within natural ecosystems and did not take into account the potential role of viruses, the combination of methods used in this study have been useful for formulating some new hypotheses and suggesting new experimental approaches in aquatic microbial ecology.

The bacterial production was probably limited in Mesocosms A and B by phosphate and nitrogen, respectively. Similar $P$ limitation has already been demonstrated for Mediterranean bacterial communities (Thingstad \& Rassoulzadegan 1995). In all situations, including the control, we observed a more or less important increase of total bacterial counts rapidly controlled by grazing. In all cases, the abundances before nutrient supply and after grazing were almost similar. However, the production, physiological state, genetic diversity and size distribution of the communities were subjected to important changes.

\section{Active cells and production}

The fraction of active cells is often based on determinations of the activity of the electron transport system by tetrazolium salts such as INT and CTC (Zimmermann et al. 1978, Rodriguez et al.

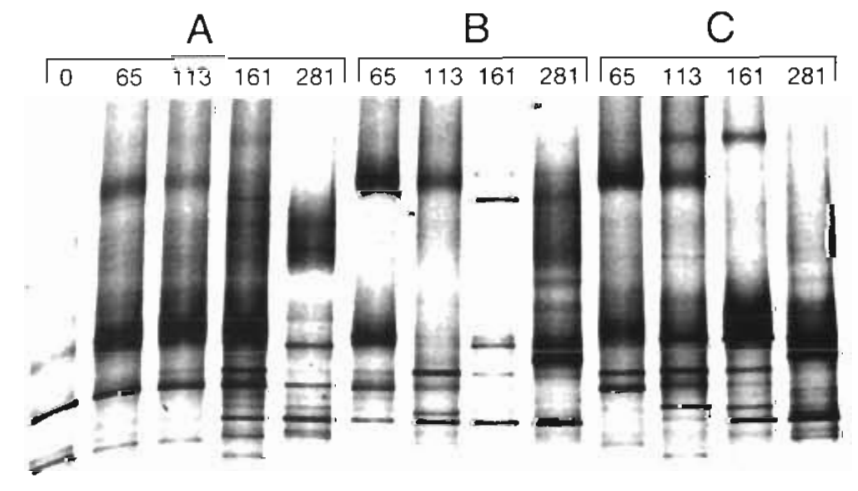

Fig. 6. Negative image of ethidium-bromide stained DGGE (denaturing gradient gel electrophoresis) gel showing the DGGE patterns of PCR (polymerase chain reaction) products obtained from mesocosm samples with the primer combinations $341 \mathrm{~F}-\mathrm{GC} / 907 \mathrm{RC}$. The origin of the samples is indicated with a letter corresponding to the mesocosm ( $A, B$ and $C$ ) and the time of sampling in hours 


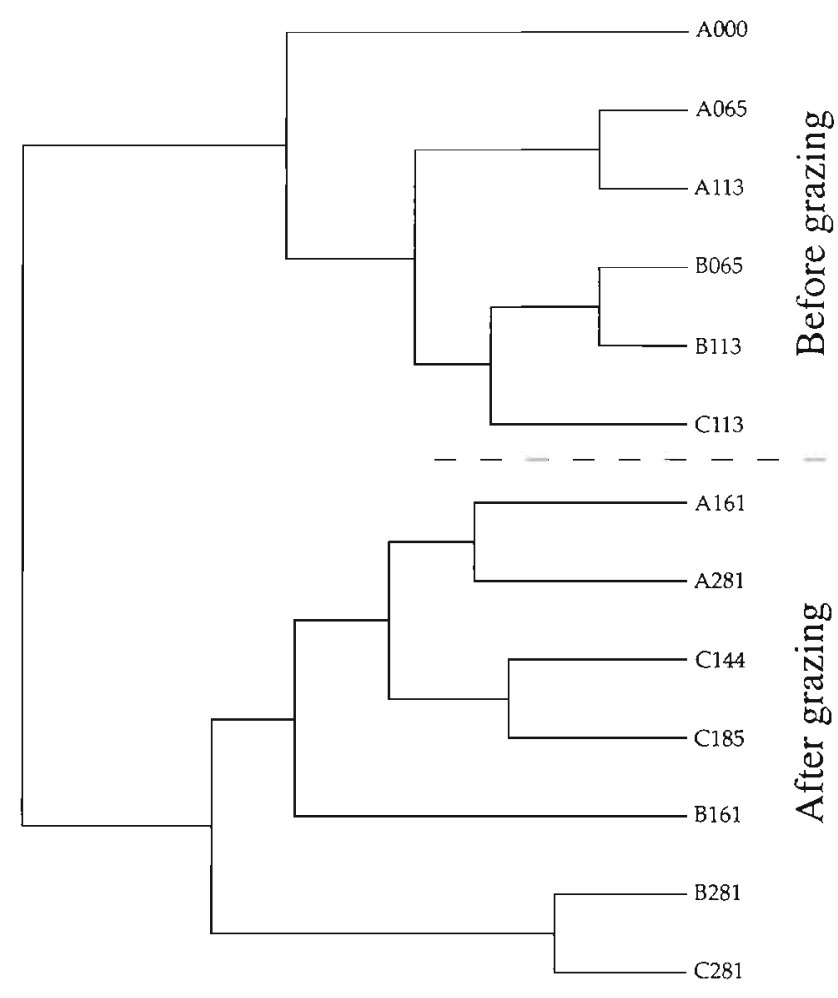

Fig. 7. Dendrogram showing the similarity of DGGE patterns from different sampling times and mesocosms (derived by UPGMA cluster analysis)

1992). Although this method has limitations (Thom et al. 1993, Lovejoy et al. 1996, Ullrich et al. 1996), it has been shown that the number of actively respiring cells determined by CTC reduction is generally well correlated with bacterial production estimates [thymidine (TdR) and leucine (Leu) incorporation rates] and that the active cell counts vary in an ecologically interpretable manner (del Giorgio \& Scarborough 1995).

The high correlation between the number of active bacteria and the global incorporation rates suggests that at a given time only a small fraction of the bacteria within natural communities participates in nutrient cycling (Table 3). Better correlations could probably be obtained by quantifying respiration, since the respiration rate of a single cell may vary depending on its metabolic activity and, thus, on its productivity. However, if we assume that these detectable respiring cells are those which participate in cell production, average growth rates can be estimated more accurately than with total cell counts.

Generation times estimated from total bacterial counts varied from 2.4 to $346 \mathrm{~h}$. Inversely, the specific growth rates calculated for each sampling time for active bacteria ranged from 0.93 to $0.11 \mathrm{~h}^{-1}$ and correspond to doubling times of $44 \mathrm{~min}$ to $6.02 \mathrm{~h}$ (Table 4). These doubling times were in good agreement with those reported in the euphotic zone of winter waters in the Gulf of St. Laurent by Lovejoy et al. (1996). The very short generation times reported in this study can be explained by an underestimation of active cells due to the low sensitivity of the CTC detection by microscopic methods, by the selection of species which cannot reduce tetrazolium salts, or by inappropriate application of a single conversion factor to transform thymidine incorporation rates into cell production. Although these limitations may contribute to these low generation times, strong modifications were observed in each mesocosm. The shorter generation times were observed after the decrease of protozod counts, suggesting that bacteria which escaped grazing were very active cells. The mean generation time calculated after the decrease of total and active cell counts (at times $185 \mathrm{~h}$ in Mesocosm A and $161 \mathrm{~h}$ in Mesocosms B and C) was short and varied between 44 and $59 \mathrm{~min}$ when calculated based on active cells.

\section{Active cells and size distribution}

The high growth rate of bacteria after grazing may be related to significant changes in the cell size distribution. In Mesocosms $\mathrm{A}$ and $\mathrm{B}$, there was an increasing fraction of large and small cells with a high and low contribution to apparent total biovolume, respectively. The high growth rate reported in Mesocosm A at 185 h was concomitant with the presence of very large cells representing more than $80 \%$ of the total biovolume. In Mesocosm C, the selection of small and large cells was also observed but was less pronounced, probably because the physiological state of the community was more active at the onset of the nutrient supply and resulted in a very rapid growth of bacterial cells and control by protozoa (see below). In all cases, the question whether large cells have a higher contribution than small cells to the whole community production remains unclear. However, the high growth rates reported in Mesocosm A in the presence of large cells suggest that these cells were very productive. A positive relationship between cell size and activity has already been suggested in the literature (Bird \& Kalff 1993, Gasol et al. 1995).

Table 3. Matrix of coefficients of determination $\left(r^{2}\right)$ for total bacterial abundance (Tot), abundance of active cells (Act), leucine (Leu) and thymidine (TdR) incorporation rates. Data are $\log _{10}$-transformed, $\mathrm{n}=32, \mathrm{p}<0.001$ for all values

\begin{tabular}{|lccc|}
\hline & Act & Leu & TdR \\
\hline Tot & 0.727 & 0.553 & 0.447 \\
Act & & 0.734 & 0.815 \\
Leu & & & 0.810 \\
\hline
\end{tabular}


Table 4. Bacterial growth rates $\left(\mathrm{h}^{-1}\right)$ calculated from cellular production and abundances of active cells (or total cell counts) at different sampling times of each mesocosm ( $A, B$ and $\mathrm{C}$ ). nd: not determined

\begin{tabular}{|lccc|}
\hline Time $(\mathrm{h})$ & $\mathrm{A}$ & $\mathrm{B}$ & $\mathrm{C}$ \\
\hline 0 & $0.164(0.002)$ & $0.336(0.004)$ & $0.408(0.002)$ \\
42 & $0.316(0.033)$ & $0.598(0.156)$ & nd \\
65 & $0.674(0.061)$ & $0.439(0.098)$ & nd \\
89 & $0.127(0.014)$ & $0.285(0.074)$ & nd \\
113 & $0.115(0.016)$ & $0.245(0.073)$ & $0.256(0.039)$ \\
122 & nd & nd & $0.605(0.166)$ \\
137 & nd & nd & $0.439(0.280)$ \\
144 & nd & nd & $0.307(0.191)$ \\
161 & $0.171(0.023)$ & $0.850(0.087)$ & $0.697(0.124)$ \\
185 & $0.933(0.054)$ & nd & $0.720(0.126)$ \\
\hline \multicolumn{4}{r}{} \\
\hline
\end{tabular}

\section{Grazing effect on active cells and size distribution}

Little is known about the effect of size selection on both taxonomic diversity and productivity of communities. Gasol et al. (1995) suggested that protozoa preferentially crop the active portion of the bacterial community if they select their prey according to size, considering that activity is related to cell size. Recently, Pernthaler et al. $(1996,1997)$ suggested that 'bacteria can adopt at least two distinct strategies as a reaction to intense flagellate predation: to outgrow predation pressure or to develop inedible, inactive filaments'. Vibrio species should be able to form chains composed of several cells as a defense mechanism against protistan attacks (Jürgens \& Güde 1994, Jürgens et al. 1997, Hahn \& Höfle 1998).

We have shown that during the initial phase of increasing production there was a shift in cell sizes from the small size class to the middle size class and then this fraction of new cells was selectively removed by protistan grazers. Similarly, the fraction of active cells was rapidly consumed during the grazing phase, suggesting that the proportion of metabolically active cells was strongly top-down controlled. The effect of grazing on the productivity of the whole bacterial communities in the 3 mesocosms confirms that it affects preferentially the fraction of active cells. Selective grazing allows the persistence of an important pool of large and small cells. These results are in good agreement with other reports (Gasol et al. 1995, del Giorgio et al. 1996b). Although the inactivity of small cells is not demonstrated, the persistence of large cells may be responsible for the maintenance of a significant level of bacterial production. However, further investigations should be done using these methods to better investigate the relationship between cell size and growth rates. The use of flow cytometry and cell sorting combined with leucine incorporation may be one way to overcome methodological limitations. The potential role of viruses was not considered in this study, but one should keep in mind that viruses may also shape bacterial communities as recently suggested in freshwaters in relation with bacterial size classes (Weinbauer \& Höfle 1998).

\section{Grazing and defense mechanisms}

In Mesocosm B, the active and culturable cells increased simultaneously during the first $48 \mathrm{~h}$ and then, surprisingly, the active fraction was almost stabilized while the culturable fraction continued to increase. This can be explained by the production of small inactive cells which retain culturability during the growth phase. However, the production of nonactive cells during the growing phase in Mesocosm $B$ remains unclear. It could be due to the rapid inactivation of cells during the growing phase as suggested by del Giorgio \& Scarborough (1995) and del Giorgio et al. (1996b). We hypothesise that some bacterial species may produce large active and small inactive cells during the growth phase as a strategy to escape grazers. They may produce at each cell division a small inactive cell and a large active cell. This strategy should be an alternative to the maintenance of high growth rates (Pernthaler et al. 1996). However, the formation of small and large cells as defense mechanisms to escape to grazers can result from different and co-existing strategies which may be developed by different species: species producing small or large cells, and species producing small and large cells, as hypothesised above. These strategies may be partly explained by genetic analysis.

If we accept that the larger the cells, the higher their productivity, the selection of large bacteria may result in the selection of a few very active and productive cells which may help to maintain bacterial production as observed in our mesocosms after grazing. However, it is not known if the filamentous bacteria grow permanently with these, with respect to grazing, advantageous morphological properties or if they express these characteristic features only under strong grazing pressure. If most of these filamentous forms express these features only under grazing pressure, their selection may have little effect on the taxonomic structure and, thus, on the functioning of natural communities.

\section{Changes in genetic diversity}

The initial culturable community was characterized by an important diversity of bacterial species and was confirmed by the diversity of bands on the DGGE pat- 
terns. The cluster analysis of DGGE banding patterns shows that samples are divided into 2 main clusters: those samples taken before the peak in grazing activity, and those obtained thereafter. This supports the notion that grazing was an important factor, controlling not only the density of the bacterial community but also its genetic diversity. The dominant isolates belonged to Alteromonas, Roseobacter, Rhodobacter, Pseudoalteromonas and Sulfitobacter species and were also present in the late sampling points after grazing. These bacterial genera have already been found in a wide variety of marine ecosystems (Giovannoni et al. 1990, Gonzalez \& Moran 1997, Suzuki et al. 1997). The results obtained from clone libraries in Mesocosms $A$ and $B$ suggest that bacteria related to $A$. macleodii are dominant after grazing (Pukall et al. 1999). Our results suggest that some species are maintained while others were not detectable after grazing. Species which were present in the initial water and were also present after grazing, such as $A$. macleodii, may have developed defense strategies to escape predation. A size polymorphism has already been shown for P. haloplanktis and elongated multigenomic cells were observed under starvation conditions (Lebaron \& Joux 1994). This size polymorphism could explain why some species escape to predation. Although this polymorphism was not demonstrated in the presence of grazers, it may result in an indirect survival advantage for this species, but it might also be induced in the presence of grazers

The key species reported here which seem to escape grazing may be considered as a first step in understanding the effect of grazing on the taxonomic structure of natural communities and the importance of these defense mechanisms towards bacterial groups. Their identification will allow the definition of taxonomic probes for the further investigation of these questions.

\section{CONCLUSIONS}

Our results suggest that on the one hand nutrients and grazing play a key role in shaping the morphologic, genotypic and phenotypic composition of bacterial communities by regulating abundances and, on the other hand, grazing preserves a minimum background of bacterial genetic diversity since it is densitydependent and also because some marine species seem to be able to develop defense mechanisms such as rapid growth and induction of a size polymorphism. Although the role of viruses was not investigated in this study due to methodological limitations, it should also be considered in order to better understand these regulations. Furthermore, as grazing may affect the production of cells with the highest growth rates, it may eliminate preferentially the most active cells within natural communities and regulate bacterial productivity if we assume that size and activity are positively correlated. It may explain why the fraction of active cells as determined by the CTC method, although this method suffers from limitations, is often not more than 30 to $40 \%$ within marine communities. Because the increase in actively respiring cells does not correlate well with the increase of total bacterial counts, it is possible that the rapid inactivation of new cells may be one way to preserve the diversity of natural communities, since these inactivated cells may return to the background of grazing resistant bacteria and nonactive cells.

Further experiments coupling flow cytometry cell sorting based on the relative cell size of bacteria and genetic analysis of these cells will be very useful for validating some of the hypotheses presented herein. These investigations are actually in progress in our group and within the ELOISE-CHABADA project supported by the European Community. It is also important to understand to what extent similar behavior can be observed in the natural environment and how often and how long such perturbed food web structures exist

Acknowledgements. This research was supported by a grant from the European Community (ELOISE-MAS3-CT960047). We thank Nicole Batailler, Philippe Catala, Joel Grabulos, Nathalie Parthuisot and Louise Oriol for technical assistance.

\section{LITERATURE CITED}

Bird DF, Kalff J (1993) Protozoan grazing and size-activity structure in limnetic bacterial communities. Can J Fish Aquat Sci 50:370-380

del Giorgio PA, Scarborough G (1995) Increase in the proportion of metabolically active bacteria along gradients of enrichment in freshwater and marine plankton: implications on estimates of bacterial growth and production rates. J Plankton Res 17:1905-1924

del Giorgio PA, Bird DF, Prairie YT, Planas D (1996a) Flow cytometric determination of bacterial abundance in lake plankton with the green nucleic acid stain SYTO 13. Limnol Oceanogr 41:783-789

del Giorgio PA, Gasol JM, Vaque D, Mura P, Agusti S, Duarte CM (1996b) Bacterioplankton community structure: protists control net production and the production of active bacteria in a coastal marine community. Limnol Oceanogr 41:1169-1179

Delong EF, Franks DG, Allbredge AL (1993) Phylogenetic diversity of aggregate vs. free-living marine bacterial assemblages. Limnol Oceanogr 38:924-934

Ducklow HW, Carlson CA (1992) Oceanic bacterial production. Adv Microb Ecol 12:113-181

Felsenstein J (1993) PHYLIP (phylogenetic inference package) version 3.5.1. Department of Genetics, University of Washington, Seattle 
Fuhrman JA, Azam F (1982) Thymidine incorporation area measure of heterotrophic bacterioplankton evaluation in marine surface waters: evaluation and field result. Mar Biol 66:109-120

Gasol JM, del Giorgio PA. Massana R, Duarte CM (1995) Active versus inactive bacteria: size-dependence in a coastal marine plankton community. Mar Ecol Prog Ser 128:91-97

Giovannoni SJ, Britschgi TB, Moyer CL, Field KG (1990) Genetic diversity in Sargasso Sea bacterioplankton. Nature (London) 345:60-63

Gonzalez JM, Moran MA (1997) Numerical dominance of a group of marine bacteria in the a-subclass of the class Proteobacteria in coastal seawater. Appl Environ Microbiol 63:4237-4242

Hahn MW, Höfle MG (1998) Grazing pressure by a bacterivorous flagellate reverses the relative abundance of Comamonas acidovorans PX54 and Vibrio strain CB5 in chemostat cocultures. Appl Environ Microbiol 64:1910-1918

Joux F, Lebaron P. Troussellier M (1997) Succession of cellular states in a Salmonella typhimurium population during starvation in artificial seawater microcosms. FEMS Microbiol Ecol 22:65-76

Jukes TH, Cantor CR (1969) Evolution of protein molecules. In: Munro HN (ed) Mammalian protein metabolism. Academic Press, New York, p 21-132

Jürgens $K$, Güde $H$ (1994) The potential importance of grazing-resistant bacteria in planktonic systems. Mar Ecol Prog Ser 112:169-188

Jürgens K, Arndt $\mathrm{H}$, Zimmermann $\mathrm{H}$ (1997) Impact of metazoan and protozoan grazers on bacterial biomass distribution in microcosm experiments. Aquat Microb Ecol 12: $131-138$

Kirchman D, K'Nees F, Hodson R (1985) Leucine incorporation and its potential as a measure of protein synthesis by bacteria in natural aquatic systems. Appl Environ Microbiol 49:599-607

Koroleff F (1976) Determination of ammonia. In: Grasshoff K (ed) Methods of sea water analysis. Verlag Chemie, Weinheim, p126-133

Lebaron P, Joux F (1994) Flow cytometric analysis of the cellular DNA content of Salmonella typhimurium and Alteromonas haloplanktis during starvation and recovery in seawater. Appl Environ Microbiol 60:4345-4350

Legendre P, Vaudor A (1991) The R package: multidimensional analysis, spatial analysis. Département des Sciences Biologiques, Université de Montréal

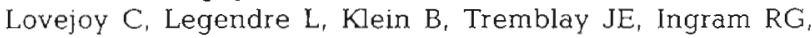
Therriault JC (1996) Bacterial activity during early winter mixing (Gulf of St. Lawrence, Canada). Aquat Microb Ecol 10:1-13

Maidak BL, Larsen N, McCaughey MJ, Overbeek R, Olsen GJ, Woese CR (1997) The RDP (Ribosomal Database Project). Nucleic Acids Res 25:109-111

Mullins TD, Britschgi TB, Krest RL, Giovannoni SJ (1995) Genetic comparisons reveal the same unknown bacterial lineages in. Atlantic and Pacific bacteriplankton communities. Limnol Oceanogr 40:148-158

Muyzer G, Teske A, Wirsen CO, Jannasch HW (1995) Phylogenetic relationship of Thiomicrospira species and their identification in deep-sea hydrothermal vent samples by denaturing gradient gel electrophoresis of $16 \mathrm{~S}$ rDNA fragments. Arch Microbiol 164:165-172

Muyzer G, Brinkhoff T, Nübel U, Santegoeds C, Schäfer $H_{\text {, }}$ Wawer C (1998) Denaturing gradient gel electrophoresis (DGGE) in microbial ecology. In: Akkermanns ADL, van Elsas JD, de Bruijn FJ (eds) Molecular microbial ecology manual, Supplement 3, 3.4.4. Kluwer, Dordrecht, p 1-27

Nei M, Li WH (1979) Mathematical model for studying genetic variation in terms of restriction endonucleases. Proc Natl Acad Sci USA 76:5269-5273

Pace $\mathrm{ML}_{1}$ Cole JJ (1994) Comparative and experimental approaches to top-down and bottom-up regulation of bacteria. Microb Ecol 28:181-193

Pernthaler J, Sattler B, Simek K, Schwarzenbacher A, Psenner $R$ (1996) Top-down effects on the size-biomass distribution of a freshwater bacterioplankton community. Aquat Microb Ecol 10:255-263

Pernthaler J, Šimek K, Sattler B, Schwarzenbacher A, Bobkova J, Psenner R (1997) Short-term changes of protozoan control on autotrophic picoplankton in an oligomesotrophic lake. J Plankton Res 18(3):443-462

Pukall $R$, Päuker $O$, Buntefuß D, Ulrichs G, Lebaron P, Bernard L, Guindulain T, Vives-Rego J, Stackebrandt E (1999) High sequence diversity of Alteromonas macleodii-related cloned and cellular 16S rDNAs from a Mediterranean Seawater mesocosm experiment. FEMS Microbiol Ecol 28 335-344

Rainey FA, Ward-Rainey NL, Kropponstedt RM, Stackebrandt $\mathrm{E}$ (1996) The genus Nocardiopsis represents a phylogenetically coherent taxon and a distinct actinomycete lineage: proposal of Nocardiopsaceae fam. Nov Int J Syst Bacteriol 46:1088-1092

Rodriguez GG, Ishiguro DP, Ridgway HF (1992) Use of a fluorescent redox probe for direct visualization of actively respiring bacteria. Appl Environ Microbiol 58:1801-1808

Saiki RK, Gelfand DH, Stoffel S, Scharf SJ, Higuchi R, Horn GT, Mullis KB, Erlich HA (1988) Primer-directed enzymatic amplification of DNA with a thermostable DNA polymerase. Science 239:487-491

Servais P (1992) Bacterial production measured by ${ }^{3} \mathrm{H}$-thymidine and ${ }^{3} \mathrm{H}$-leucine incorporation in various aquatic ecosystems. Arch Hydrobiol Beih Ergebn Limnol 37:73-81

Servais P (1995) Measurement of the incorporation rates of four amino-acids into proteins for estimating bacterial production. Microb Ecol 29:115-128

Shiah FK, Ducklow HW (1997) Bacterioplankton growth responses to temperature and chlorophyll variations in estuaries measured by thymidine:leucine incorporation ratio Aquat Microb Ecol 13:1.51-159

Suzuki MT, Rappé MS, Haimberger ZW, Winfield H, Adair N, Ströbel J, Giovannoni SJ (1997) Bacterial diversity among small-subunit rRNA gene clones and cellular isolates from the same seawater sample. Appl Environ Microbiol 63:983-989

Teske A, Wawer C, Muyzer G, Ramsing NB (1996) Distribution of sulfate-reducing bacteria in a stratified fjord (Mariager Fjord, Denmark) as evaluated by most-probable-number counts and denaturing gradient gel electrophoresis of PCR-amplified ribosomal DNA fragments. Appl Environ Microbiol 62:1405-1415

Thingstad TF, Rassoulzadegan F (1995) Nutrient limitation, microbial food webs and biological C-pump: suggested interactions in a P-limited Mediterranean. Mar Ecol Prog Ser 117:299-306

Thom SM, Horobin RW, Seidler E, Barer MR (1993) Factors affecting the selection and use of tetrazolium salts as cytochemical indicators of microbial viability and activity J Appl Bacteriol 74:433-443

Treguer P, Le Corre P (1975) Manuel d'analyses des sels nutritifs dans l'eau de mer. Utilisation de l'autoanalyser II-Technicon. Université de Bretagne Occidentale, Brest

Troussellier $M$, Courties C. Zettelmaier S (1995) Flow cytometric analysis of coastal lagoon bacterioplankton and 
picophytoplankton: fixation and storage effects. Estuar Coast Shelf Res 40:621-633

Troussellier M, Courties C, Lebaron P, Servais P (1999) Flow cytometric discrimination of bacterial populations in seawater based on SYTO 13 staining of nucleic acids. FEMS Microbiol Ecol 29:319-330

Ullich S, Karrasch B, Hoppe HG, Jeskulke K, Mehrens M (1996) Toxic effects on bacterial metabolism of the reodx dye 5-cyano-2,3-ditolyl tetrazolium chloride. Appl Environ Microbiol 62:4587-5493

Ward DM, Weller R, Bateson MM (1990) 16S rRNA sequences

Editorial responsibility: Frede Thingstad,

Bergen, Norway reveal numberous uncultured microorganisms in a natural community. Nature 345:63-65

Ward JH (1963) Hierarchical grouping to optimize an objective function. J Am Stat Assoc 58:236-244

Weinbauer MG, Höfle MG (1998) Size-specific mortality of lake bacterioplankton by natural virus communities. Aquat Microb Ecol 15:103-113

Zimmermann R, Iturriaga R, Becker-Birck J (1978) Simultaneous determination of the total number of aquatic bacteria and the number there of involved in respiration. Appl Environ Microbiol 36:926-935

Submitted: November 7, 1998; Accepted: May 3, 1999 Proofs received from author(s): October 11, 1999 